\title{
Analysis and Countermeasure Research on Electronic Resources Utilization in Vocational College
}

\author{
Lixue Chen ${ }^{1}$, Nan Ding ${ }^{1}$, Yabin $\mathrm{Gao}^{2}$ and Zhiqiang $\mathrm{Wu}^{3}$ \\ ${ }^{1}$ Hebei Vocational \& Technical College of Building Materials, Qinhuangdao 066004, \\ Hebei, China \\ ${ }^{2}$ Hebei normal university of science and technologyQinhuangdao 066004, Hebei, \\ China \\ ${ }^{3}$ Qinhuangdao electric power companyQinhuangdao 066004, Hebei, Chind \\ snma@163.com
}

\begin{abstract}
Based on the library questionnaires of Hebei Vocational \& Technical College of Building Materials in 2013, this paper analyzes the status and causes of electronic resources utilization. After the analysis, this paper puts forward the corresponding countermeasure on how to improve the utilization of electronic resources in vegtional colleges in an attempt to push on the promotion and utilization of electronic resources.
\end{abstract}

Key words: vocational college libraty; electronic resources; utilization

With the booming of information age, dramatic change also happened to the type and structure of university library collections. Electronic resources have taken the essential component of college, library collections. Vocational colleges have been stepping up efforts to expand the collection of electronic resources.

Yet the current status of electronic resources in vocational colleges is not optimistic. This paper takes the Hebei Vocationaland Technical College of Building Materials as an example, summarizes the current status and problems of electronic resources utilization in vocational college library, and proposes countermeasures to provide reference and guidance for future construction of electroncuresources.

\section{Research method and results}

\subsection{Research method}

The questionnaires were conducted among sophomores and junior students of all six departments in the west campus of Hebei Vocational and Technical College of Building Matenals, probing in the self-study room, information retrieval room, two reading rooms in the library, canteen and teachers' office. One thousand copies of questionnaires were delivered, with 1,000 valid copies returned. The survey consists of 12 questions within four items, of which a few questions do not have feedback by the respondents.

\subsection{Research results}

The questionnaire results are shown in charts 1-4. 
Chart 1. Readers' Questionnaire

\begin{tabular}{|c|c|c|c|c|c|}
\hline \multirow{2}{*}{$\begin{array}{l}\text { Do you often use } \\
\text { the electronic } \\
\text { resources in the } \\
\text { library? }\end{array}$} & $\begin{array}{l}\text { Often (teachers } \\
\text { and students) }\end{array}$ & \multicolumn{2}{|c|}{$\begin{array}{l}\text { Occasionally / seldom(teachers and } \\
\text { students) }\end{array}$} & \multicolumn{2}{|c|}{$\begin{array}{l}\text { Do not use (teachers and } \\
\text { students) }\end{array}$} \\
\hline & 240 & \multicolumn{2}{|r|}{540} & \multicolumn{2}{|c|}{220} \\
\hline \multirow{2}{*}{$\begin{array}{c}\text { What kind of } \\
\text { electronic } \\
\text { database do you } \\
\text { often use? }\end{array}$} & cnki & appabi & University digital & sslibrary & High- quality \\
\hline & 270 & 150 & 220 & 60 & 150 \\
\hline \multirow{2}{*}{$\begin{array}{l}\text { Why don't you } \\
\text { often use } \\
\text { electronic } \\
\text { resources? }\end{array}$} & Do not familiar & Slow speed & $\begin{array}{l}\text { Lack of computers } \\
\text { accessible to } \\
\text { campus network }\end{array}$ & $\begin{array}{l}\text { Poor } \\
\text { electronic } \\
\text { resources }\end{array}$ & \\
\hline & 180 & 50 & 160 & & 480 \\
\hline \multirow{2}{*}{$\begin{array}{c}\text { How do you rate } \\
\text { the electronic } \\
\text { resources? }\end{array}$} & Excellent & Good & & & \\
\hline & 180 & 390 & & & \\
\hline
\end{tabular}

\section{Chart 2. Readers' Attitude to Eleçtronic Resources}

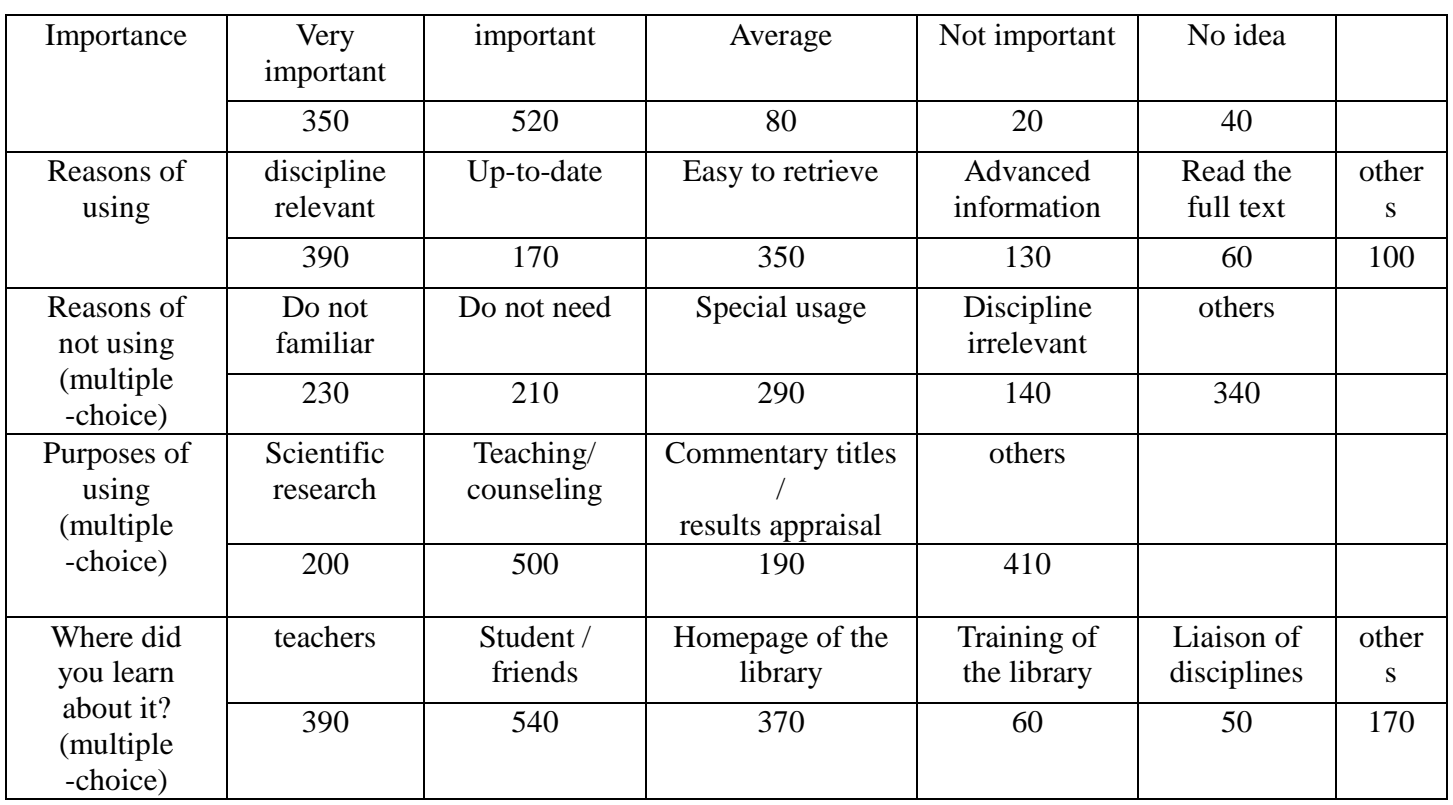

\section{Chart 3. The Frequency and Ways to Utilize Electronic Resources of Users}

\begin{tabular}{|c|c|c|c|c|c|}
\hline \multirow{2}{*}{$\begin{array}{l}\text { The average time of } \\
\text { using the library's } \\
\text { electronic resources per } \\
\text { week }\end{array}$} & 0 -1 time & 2-4 times & 4-7 times & More than 7 & \\
\hline & 550 & 390 & 20 & 40 & \\
\hline \multirow{2}{*}{$\begin{array}{l}\text { The place to use the } \\
\text { library's electronic } \\
\text { resources }\end{array}$} & E-reading room & Home & Office & Lab & Office \\
\hline & 570 & 340 & 70 & 10 & 10 \\
\hline
\end{tabular}




\section{Chart 4. Comments and Suggestions}

\begin{tabular}{|c|c|}
\hline $\begin{array}{c}\text { Items about the type and quantity of the electronic } \\
\text { resources }\end{array}$ & \begin{tabular}{c} 
Items about the hardware issues of the e-reading room \\
\hline 410
\end{tabular} \\
\hline Items about the working efficiency of the library & Items about landing outside the campus \\
\hline 80 & \\
\hline
\end{tabular}

\section{Analysis of the utilization status and questionnaire results of electronic} resources

Chart 1 shows: the utilization of the electronic resources is unisatisfactory.

Current status: "Occasionally / seldom" accounts for 54\%, "Do not use" is basically flat with "Often", which accounts for 20\%; "Do not familiar" takes 18\%; "Others" reaches 48\%. However, the utilization of the electronicoresources of ounlibrary makes little difference.

Chart 2 shows: readers have a knowledge paucity of electronic resources

Current status: "Do not familiar", "Do not need"and "others" accounts for over 50\% respectively. But about $80 \%$ resfondents acknowledge that it is "Very important" or "Important", which proves there is a huge demand for electronic resources. Unlike the requirements of the universities, the main purpose of the respondents to use the electronic resources concentrates in "Sclentific research", "teaching" and "commentary titles", which bears a certain relationship with the academic atmosphere in vocational college. More striking, the ways to learn about the electronic resources is a further illustrative item. Acquaint by "teachers" or "students" takes more than $50 \%$, by "Homepage of the library" holds $30 \%$, by "liaison of disciplines" accounts for less than $10 \%$.

The frequency of utilizing electronic resources in chart 3 shows: "0-1 time" accounts for 50\%; "2-4 times" takes 40\%; "more than 4 times" holds less than 10\%. Through checking the background supporter of cnki, the landing time of users' IP are rare but the period of thesis writing. The landing location mostly concentrates in the "e-reading room" and "home". The reason should frace back to chart 1,20\% of the respondents chose "slow speed" and "lack of computers accessible to campus network". 60 aging configuration of computers in the e-reading room results in low utilization of electronic resources.

Chart 4 offers humanized questionnaire on the comments and suggestions: Among the questions, "items about types and quantities" comes to $40 \%$, "items about software" takes $30 \%$, "items about landing outside the campus" accounts for $20 \%$. Instead of marking a " $\sqrt{ }$ " as required, different feedbacks are showed in a unique questionnaire. For the sections of "Items about the hardware issues of the e-reading room" and "items about landing outside the campus", the answers are "not good". "Items about the working efficiency of the library" is commented as "inefficient". "Items about the type and quantity of the electronic resources" get "few". The result suggests that readers have many grievances for the library's electronic resources. Of course, similar problems occur in the library of many universities. The result of a electronic resources utilization survey among college students which is conducted by the Educational Technology Department of Wenzhou University shows that problems exist in the ways to approach the electronic resources, and the utilization of the professional electronic database is quite low [1].By the end of 2005, Shanghai Jiao Tong University conducted an internet survey on "library resources and services" among all the teachers and students. The survey shows that the utilization of the library's electronic resources among undergraduate student is low [2]. The library of Tsinghua University launched the same survey in 2006, it 
reveals nearly $1 / 4$ of their undergraduate students never use any electronic resources [3]. According to the survey of the library of Beijing Normal University on the teachers' dependency towards library resources in 2006, it turns out that there appears a certain gap in the teachers' actual and imaginary dependency [4].

\section{Reasons and solutions}

Based on the data analysis, the writer summarizes causes of current situation and proposes the corresponding countermeasures as follows:

\subsection{Inadequate promotion}

Of all the librarians as well as the curator, only one majors in library. As a result, we are not qualified to provide the courses of information retrieval and students are therefore blind when writing their papers. They are looking for information from the internet and even do not know the existence of electronic resources. On the other hand, the library does hot offer any information about the electronic resources and those information-seeking students actually watch videos, chat online or update their microblogs. The infolmation retrieyal room has been converted into a cyber café. Most teachers and students are not proficient at information retrieval, most of whose uses have been negledted in this way. They tend to input the information, google or baidu and get the related results, but they are unable to explore the explore and analyze the results and thus the powerful database is not made full use of. The electronic resources in our school have never been well'utilized since they were purchased in 2007. There are no training classes or promotional materials. In April, 2013, our library and the Student Affairs Department organized an activity called "Into the Library" and this was the first time that the library had been introduced to the students, including junior and even senior students. After this actixity experience has been accumulated and the library has made a short video program to introduce itself io the freshmen after their enrollment, involving its layout, organizations, functions and tesources, which receives a very good feedback and marks a new beginning as well.

\subsection{Solutions}

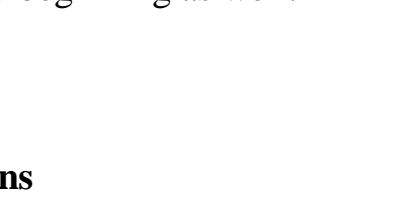

3.2.1.

It is essential to improye librarians' professional qualities and build up a professional team. The library is expected to be qualified for information retrieval courses and this is the best way to help the library better known.

3.2.2.

Post some pictures and words in the sight-catching places of the library. 3.2.3.

Set the webpage of electronic resources as the homepage of the information retrieval and offer efficient and effective approaches to information retrieval.

3.2.4.

Organize some reading activities such as Readers' Day and lead the readers into the library. This is not a promotion to the campus atmosphere, but also the responsibility of the library. 3.2.5.

Cooperate with the resources providers and give training classes to the teachers and students, making them better know the electronic resources a ad the electronic resources better utilized.

\subsection{Restrictions}

The server of the electronic resources is in the network center and only those who have access to the server are able to log on. Teachers can easily search or download in the offices or labs. But to the students, only two places are available to information searching, one is the dorm and the other is the information retrieval room. The dorm net is unable to log on, but there are totally 60 old computers in the information retrieval room, which cannot meet the 
needs of a total number of over 3000 students and this also contributes to the low utilization of the electronic resources.

\subsection{Solutions}

\subsection{1.}

Enlarge the network coverage and set access right in the audiovisual classrooms and the students' dormitories, helping students search and download the needed materials.

3.4.2.

Add more computers to the information retrieval room and see to it that 4-5 students are equipped with one computer. Upgrade the computers and solve the problem of slow speed.

3.4.3.

Set restrictions to the outside-school visits and make full use of the idle resources. There are altogether 50 accounts to the outside-school visitors, but only ten of them are in use. Students know nothing about this and it can be utilized and improve utilization efficiency. 3.4.4.

A Quick Response Code is available on the library homepage and students dan scan it with their phones and gain access to the library homepage. Meanwhile, a mobile reading room is being planned with Wifi available. In this way, students are able to use the internet without any expense and the problem of low utilization of electronic resources is going torbe solved.

\subsection{The electronic resources}

Generally speaking, a vocational school is not intended to purchase many Masters and Doctors' theses because of a lack of readers. Besides, teachers and students do not often need the data in foreign languages and some seldom-visited electronic resources are out of use. This greatly lowers the utilization.

\subsection{Solutions}

3.6.1.

Purchase the database which matches the majors of our school and make electronic resources well utilized and expenses avell spent.

3.6.2.

Keep the provision or the electronic resources steady and be well responsible of the management of the electronic resources. If there should be any problem, contact the technical department and communicate with the datapase provider to make sure that the problem is solved and the provision of electronic resources steady.

3.6.3.

Establish a cooperative relationship between the library and the school network center. With the support of both software and hardware, independently develop the information retrieval approaches to electronic resoutces and uplift the utilization of the school electronic resources.

3.6.4.

Trial electronic resources, the library as the trial databases, electronic information producer or the distributor to sell your product, strive for more customers, provided by the library users before ordering a free trial and demonstration of various commercial electronic resources. It is one of the means to improve the library database resources. The probation period is commonly $3 \sim 6$ months. Library can make full use of it, before the purchase of electronic resources on a large number of emerging new trial electronic resources, through the new production database for effective management and evaluation, is conducive to the right decisions, make the electronic resources construction rationalization, scientific, and the introduction of scientific and reasonable scheme. At present, our trial database ten thousand, super magnitude.

\section{Conclusion}

In one word, this questionnaire survey is important and necessary because it displays the utilization and the weight of the literature resources in our school. Through investigation and analysis, problems are positioned and the future development of the library is well planned. Promotion to the electronic resources needs to be strengthened and talents with information retrieval capacities need to be cultivated. Provide safe and steady network technical service and well distribute the expenses according to the utilization of the electronic resources. Alter 
the present situation, uplift the efficiency of the electronic resources and offer best services to all the teachers and students and make contributions to school culture.

\section{Acknowledgments}

The thesis is a Concluding paper of a subject Qinhuangdao SheKeLian in 2013 Electronic resources utilization analysis and countermeasures study in higher vocational colleges. Issue number is 201306199.

\section{References}

[1] Y. Xindong and G. W. Jing, "College students' use of electronic resources investigation and analysis [J]", Journal of modern education Technology, vol. 6, (2007) pp. 76-81.

[2] L. Fang and G. Jiang, "The library resources and services under the network environment propaganda mode Type to explore - - Shanghai jiaotong university library propaganda case analysis [J]", Journal of library journal, vol. 12, (2006), pp. 36-37.

[3] Y. Yi, S. Min and L. Jinghua, "The electronic resources construction and utilization of the reader investigation - - By readers readers using electronic resources suryey results anal sis and tendency [J]", Journal of university of figure Journal of libraries, vol. 6, (2006) pp $39-48,60$.

[4] Y. Yufang, Q. Wei and L. Peiwen, "The teacher survey of library dependence $>$ - In Beijing normal university library, for example [J]”, Journal of library work and Stady, vol. 1, (2007), pp. 71-73.

[5] Z. Lan, "Present situation and countermeasures of electronic resources in university library - - based on the research on Harbin polytechnic university library reader survey [J]", Journal of library work research, vol. 17, (2009), pp. 12-14.

[6] D. Wenyuan and W. Juanxian, "University library electronicoresources utilization survey —— in jiaxing college library, for example [J]", Journal of librafy construction, vol.9, (2008), pp. 30-33.

[7] G. Z. Yangyang, "The current situation and eountermeasares of electronic resources in colleges and universities [J]", Journal of library science research, vol. 11 (2008), pp. 85-87.

[8] S. A. Rogers "1Electronic Journal Usage at Ohio State University 1College and Libraries Research", vol. 1, (2001).

[9] D. J. Grimes and C. H. Boening, ‘1 Worries awith the Web: A Look at Student Use of Web Re-sources 1College and Libraries Research," vol. 1, (2001).

[10] K. Bauer, "1Indexes as Tools for Measuring Usage of Print and Electronic Resources 1College and Libraries Research", rol. 1, (2001).

[11] B. L. Schaffner, "1Electroníc Resourcês: A Wolf in Sheep's Clothing? 1College and Libraries Research, vol. $3,(\mathbf{2 0 0 1})$.

[12] S. D. Herring, "1Faculty Acceptance of the World Wide Web for student Research 1College and Libraries Research", vol. 3, (2001).

[13] L. McGillis and E. G. Tons. "1Usability of the Academic Library Web Site: Implication for Design1 College and Libraries ReSearch”, vol. 4, (2001).
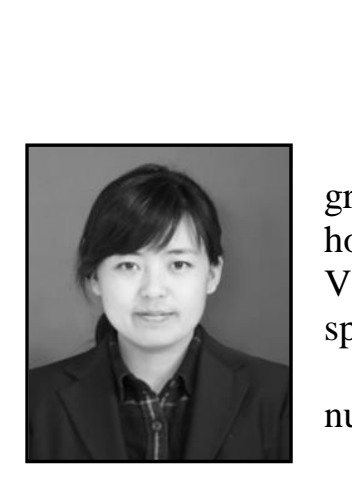

\section{Authors}

Lixue Chen, she was born in Liaoning Province, China. She graduated from Shenyang Agricultural University and majored in horticulture and started to work as a librarian in the library of Hebei Vocational and Technical College of Building Materials in 2005 and specialized in the application of electronic resources.

Fund number: Qinhuangdao Allied Social Science Association Issue number is 201306199.

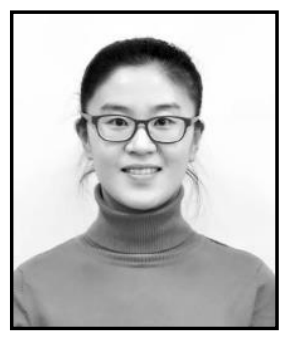

Nan Ding, she received her Master's degree in Computer Science and Technology from Yanshan University of Technology in Hebei, China Her research interest is mainly in the area of Data mining and software testing she has published several research papers in scholarly journals and international conferences in the above research areas.

Fund number: Hebei Province Office of education project JYGH2011016. 


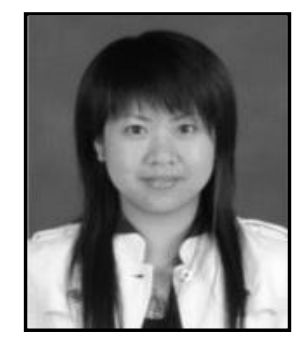

Yabin Gao, she received her master's degree of Software Engineering in Beijing University of Technology, Beijing, (2012). Now, she is a lecturer in Hebei Normal University of Science \& Technology, Qinhuangdao, Hebei. Her major fields of study are Education and teaching management, software engineering and education.

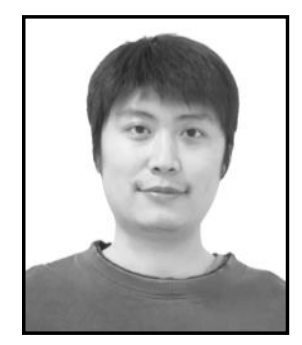

Zhiqiang Wu, he is from Hebei province and graduated from north China electric power university in mechanical engineering and automation, 2006 workers to qinhuangdao electric power companly, the primary electrical engineer, now work in the electric power operation. 
International Journal of Multimedia and Ubiquitous Engineering

Vol.9, No.5 (2014)

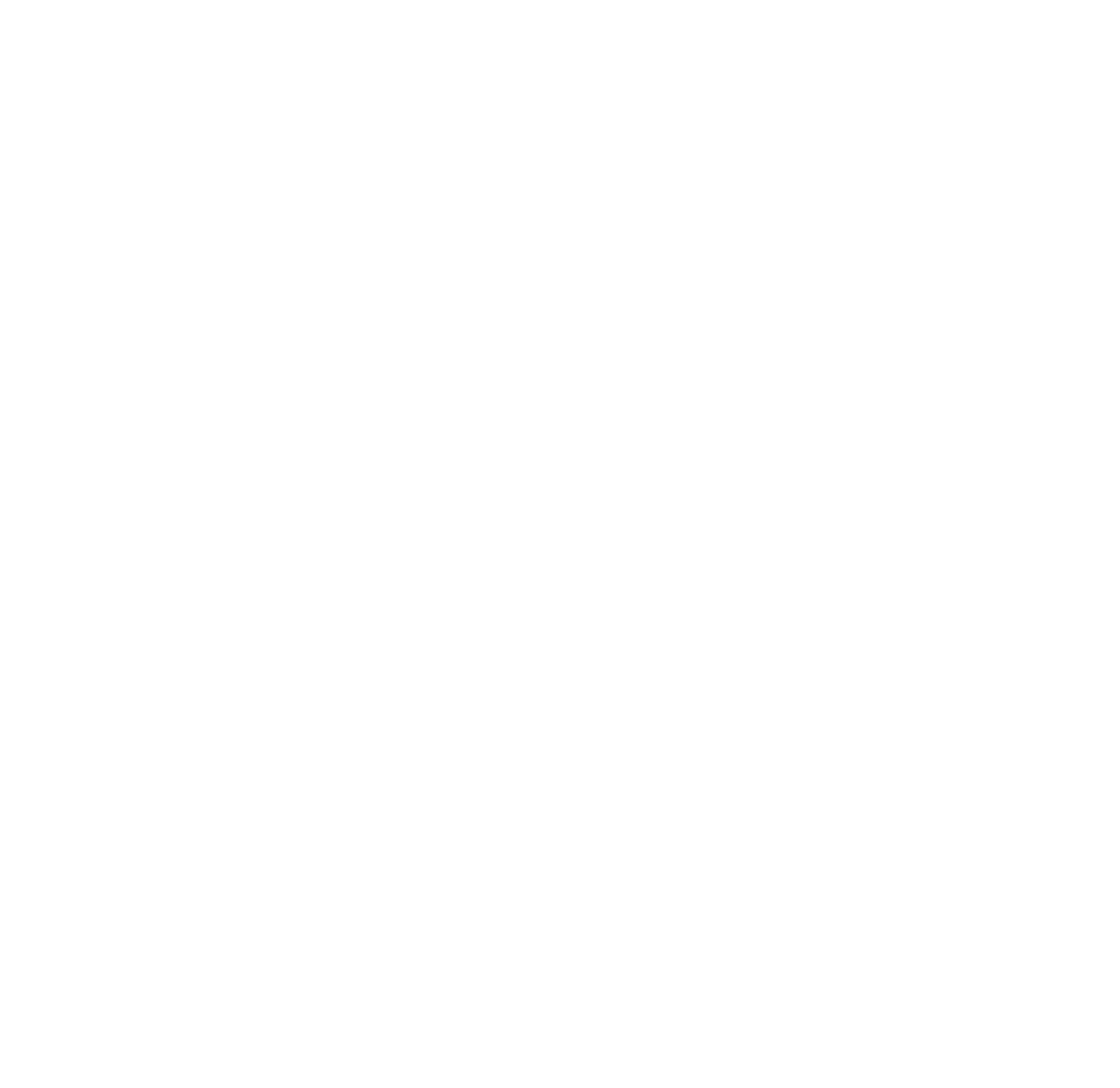

